\title{
ZMIANY POLITYCZNE W ŚWIECIE ARABSKIM ANNO DOMINI 2011. PRÓBA OCENY Z PERSPEKTYWY STRATEGICZNEGO BEZPIECZEŃSTWA IZRAELA
}

Koniec roku 2010 i początek 2011 w krajach arabskich przeszedł do historii pod nazwami „Arabska Wiosna Ludów” oraz „Arabskie przebudzenie”, ponieważ w tym okresie doszło do masowych protestów społecznych o podłożu politycznym i ekonomicznym w prawie wszystkich państwach regionu. Trudno rozpatrywać jakiekolwiek zmiany na Bliskim Wschodzie, bez uwzględnienia specyficznego miejsca i roli Izraela. To co ważne dla regionu i całego świata, dla Izraela oznacza konieczność oceny z perspektywy jego bezpieczeństwa, dotychczasowego układu sił, korzyści i strat związanych ze zmianami, prognoz dotyczących procesów politycznych i społecznych w kontekście zagrożeń, prognoz długoterminowych bez charakterystycznego entuzjazmu dla zmian samych w sobie.

Bliski Wschód kreuje swoją tożsamość, jest to proces jej konfrontacji, w niedalekiej przyszłości musi podjąć decyzję o stosowaniu lub niestosowaniu przemocy. Przemoc to między innymi chęć realizacji zamierzeń przy użyciu siły, kierowanie swoich działań na konfrontację. Z uwagi na charakter, dynamikę oraz podłoże konfliktu arabsko-izraelskiego, każda istotna zmiana w krajach arabskich ma i musi mieć istotne znaczenie dla Izraela oraz całego Bliskiego Wschodu.

Pomimo dynamiki zmian, władze Izraela muszą pamiętać o rzeczywistym czasie procesów. Ewentualny kryzys, zaostrzenie konfliktu odbije się negatywnie na sytuacji całego świata. Nim jakiekolwiek skutki odczuje świat w wymiarze globalnym, dla Izraela może oznaczać to kres jego egzystencji. Dlatego od dziesięcioleci, po doświadczeniach kolejnych konfliktów zbrojnych, wojskowi, politycy oraz społeczeństwo Izraela, mają świadomość, iż strategia bezpieczeństwa tego państwa musi uwzględniać brak drugiej szansy. Przegrana może oznaczać jedynie koniec państwa i fizyczne zagrożenie dla egzystencji Narodu Żydowskiego na tym obszarze. Dlatego analitycy izraelscy są zmuszeni do brania pod uwage podczas oceny arabskiej wiosny, przede wszystkim czynników mogących mieć negatywny wpływ na bezpieczeństwo w regionie oraz konsekwencje w odniesieniu do Izraela. Euforia medialna czy entuzjazm polityczny, charakterystyczny dla ocen przemian demokratycznych w tej części świata przez państwa spoza regionu, dotyczy to również USA i UE, dla Izraela oznacza alert, konieczność przewartościowania.

Przy analizie tak wielowątkowego i dynamicznego fenomenu, należy postawić właściwe pytania badawcze, unikając przy tym punktu widzenia charakterystycznego dla komentatorów politycznych oraz samych polityków oceniających zjawiska z per- 
spektywy swoich wyborców, a nie realiów występujących w danym miejscu i czasie, silnie związanych z sytuacją społeczno-historyczną i kulturową. Postrzegając analizowane zjawisko z perspektywy Bliskiego Wschodu, konfliktu arabsko-izraelskiego oraz sytuacji zewnętrznej i wewnętrznej Izraela w wymiarze strategicznym, szczególnie ważna jest próba odpowiedzi na następujące pytania:

- Czy oraz w jakim stopniu „Arabska wiosna” wpłynęła na zmianę sytuacji strategicznej Izraela?

- Czy zmiany mające miejsce w regionie mają potencjalne znaczenie dla konfliktu arabsko-izraelskiego?

- Czy Izrael tracąc swoich sojuszników takich, jak Egipt czy Turcja, zyskuje innych?

- Jak zmiany w regionie, sposób jego postrzegania wpływa na USA i UE, głównych sojuszników Izraela?

- Jaki wpływ zmiany te mają na pozycję jego głównego, strategicznego przeciwnika - Iran?

Szczególnie przydatna w próbach odpowiedzi na te pytania staje się analiza kompleksowa. Bazuje ona na założeniu, iż nie ma jednego typu, modelu, drogi rozwoju, występuje wielość typów i modeli. Podejście kompleksowe powinno uwzględniać, elastyczną i przyswajalną politykę państwa, przy założeniu, iż nie ma prostych, politycznych odpowiedzi na wszystkie sytuacje.

Nie należy zapominać, iż konflikt arabsko-izraelski ma charakter etniczny, religijny, terytorialny oraz cywilizacyjno-kulturowy zarazem. Nie można go postrzegać jedynie z perspektywy rozpoznawalnych dla cywilizacji euroatlantyckej wyróżników tj. demokracja, prawa człowieka, tolerancja, ład i porządek kreowany i kontrolowany przez instytucje międzynarodowe. Na jego wymiar istotny wpływ miały i mają nastroje społeczne, rywalizacja w obrębie elit oraz grup religijnych, a także podmiotów zewnętrznych wykorzystujących symbolikę sporu dla swoich interesów wewnętrznych i międzynarodowych.

\section{SYTUACJA STRATEGICZNA IZRAELA PRZED 2011 ROKIEM}

Rozpatrując sytuację strategiczną Izraela, należy spojrzeć na nią z perspektywy Tunezji, Egiptu, Libii, Syrii, a także innych państw regionu, w których nie doszło do tak spektakularnych wydarzeń jak ucieczka Ben Alego, upadku H. Mubaraka czy zabójstwa M. Kadafiego ${ }^{1}$. Celem nie jest koncentracja na aspektach obronnych, związanych z parametrami o charakterze militarnym - w realiach czysto wojskowych, mierzonych parametrami ilościowymi i jakościowymi, Izrael jest potęgą regionalną, niemającą sobie równych na Bliskim Wschodzie. Bardziej istotne są kwestie polityczno-społeczne, ponieważ w realiach Bliskiego Wschodu wielomilionowe społeczeństwa tzw. ulica

${ }^{1}$ Mniej lub bardziej radykalne formy protestów miały miejsce również w Algierii, Jordanii, Jemenie, Libanie, Maroku czy Mauretanii Prezydent Tunezji Zin Al-Abidin Ben Ali uciekł z tego kraju 14 stycznia 2011 roku. Prezydent Egiptu Hojni Mubarak został obalony 11 lutego 2011 r., a jego proces toczy się przed trybunałem wojskowym w Kairze. Przywódca Libii Muamar Kadafi został pojmany i zabity przez rebeliantów 20 października 2011 r. Powstanie przeciwko reżimowi Asad'a w Syrii trwało w chwili pisania tego artykułu (koniec grudnia 2011). 
była niejednokrotnie siłą sprawczą konfliktów z udziałem wielomilionowych armii i stratach ludzkich, a także sprzętowych na wielką skalę.

Postrzegając kraje arabskie z perspektywy systemów politycznych, można było wprowadzić generalny podział na państwa, w których władza sprawowana była i jest przez reżimy świeckie niebędące monarchiami oraz monarchie. Zarówno w jednych, jak i drugich radykalne ugrupowania islamskie dążyły i dążą do zmiany charakteru państwa, a ich siła i poparcie społeczne jest zróżnicowane. Radykalne ruchy islamistyczne otrzymywały ciagłe wsparcie ze strony Islamskiej Republiki Iranu, natomiast pragmatyczne reżimy świeckie dążyły do utrzymania władzy. W ich strategicznym interesie było utrzymanie poprawnych relacji z Zachodem, a szczególnie ze Stanami Zjednoczonymi będącymi naturalnym wsparciem ich interesów politycznych, ekonomicznych oraz militarnych. Ze strategicznego punktu widzenia rzeczą oczywistą było, iż dopuszczenie w państwach arabskich do wolnych, demokratycznych wyborów spowoduje prawdopodobne zwycięstwo ruchów i partii islamistycznych ${ }^{2}$.

Postrzegając sytuację z tej perspektywy, utrzymywanie się reżimów politycznych, niedopuszczających do ekspansji Radykalnego Islamu, traktującego Zachód jako kulturowego i cywilizacyjnego wroga było korzystne dla Izraela ${ }^{3}$. Należy pamiętać, iż zwalczający się wzajemnie szyici i sunnici, czego przykładem może być dzisiejszy Irak, potrafią współpracować przeciwko wspólnemu wrogowi. Najlepszą ilustracjąjest wsparcie szyitów z Iranu czy Hezbollahu dla sunnitów z Hamasu walczącego zbrojnie z Izraelem ${ }^{4}$. Działania Hezbollahu oraz Hamasu wypromowały niezwykle niebezpieczną doktrynę znaną jako muquawama - Islamski Opór (arab. Al-Muqawama al-Islamiyya), neguje ona w całości Izrael oraz proces pokojowy ${ }^{5}$. Neguje również państwa arabskie i rządzące nimi reżimy polityczne, jako warunek konieczny do prowadzenia wojny z „syjonistycznym tworem”, jakim dla Islamistów jest Izrael.

Specyficzny balans między społeczeństwami (w większości przypadków sprzyjającymi ruchom islamistycznym) a reżimami politycznymi powodował niejednokrotnie wykorzystywanie antyizraelskich nastrojów, jako narzędzia w polityce wewnętrznej tych państw ${ }^{6}$. Sytuacja ta jest jeszcze bardziej skomplikowana, gdy bierze się pod uwa-

2 Można powołać się tu na przykład wyborów w Algierii (1991), Autonomii Palestyńskiej (2006) czy Iraku (2005).

3 Egipt był największym państwem, sąiadem Izraela, który poprzez podpisanie porozumienia pokojowego, dokonał symbolicznego wyłomu w relacjach „świata arabskiego" z państwem żydowskim. Tunezja, postrzegana jako sojusznik Zachodu, uznaje Izrael choć nie ma z nim od 2000 r. stosunków dyplomatycznych.

${ }^{4}$ Dzisiejsza konfrontacja między szyitami i sunnitami może być porównywana $\mathrm{z}$ historycznie znanym, a obecnie niewystępującym katolickim i protestanckim fanatyzmem religijnym, który w imię jedynego i miłosiernego Boga wyniszczał ludność Europy Zachodniej i Środkowej.

${ }^{5}$ Najczęściej jest ona charakteryzowana w następujący sposób: Pokój nie jest rozwiązaniem finalnym, może być jedynie przejściowym porozumieniem z reżimem Syjonistycznym; Walka nie toczy się o terytorium jej istotą jest systematyczne osłabienie/erozja Izraela; Dżihad nie jest celem narodowym, to powszechne dążenie; Równowaga sił nie jest konieczna, jest to jedynie strata czasu; Państwa arabskie nie są konieczne do prowadzenia wojny, wystarczą ruchy islamskie tj. Hezbollah czy Hamas. Zob.: E. Yaari, The Muquawana Doctrin, „Jerusalem Report”, 13 November 2006 http://www.washingtoninstitute.org/siteImages/spacer.gif.

6 Podczas rozpoczętej 27 grudnia 2008 r. w Strefie Gazy operacji Płynny Ołów (ang. Cast Lead) demonstracje w stolicach państw arabskich były wielokrotnie silniejsze, niż na kontrolowanym przez Autonomię Palestyńską Zachodnim Brzegu. 
gę rywalizację w regionie krajów arabskich i niearabskich, czyli Turcji ${ }^{7}$ oraz Iranu. To, co dla obserwatora z Europy lub spoza regionu może wydawać się paradoksem, w realiach Bliskiego Wschodu jest wyrazem faktycznej sytuacji związanej z faktami historycznymi i społecznymi.

To z inicjatywy świeckich reżimów politycznych doszło 28 marca 2002 r. podczas szczytu Ligi Państw Arabskich (dalej: LPA) w Bejrucie do inicjatywy zakończenia konfliktu z Izraelem. Drogą do porozumienia mają być zakończenie konfliktu i normalizacja stosunków z Syrią oraz Autonomią Palestyńską. Propozycja ta została zaakceptowana przez Szczyt LPA w Rijadzie odbywający się w dniach 27-28 marca 2007 roku $^{8}$. Deklaracja jednoznacznie opowiada się za możliwością normalizacji stosunków między 22 państwami arabskimi i Izraelem, co w praktyce miałoby oznaczać formalne uznanie tego państwa nie tylko przez nie, lecz również przez 57 państw muzułmańskich $^{9}$.

Swoistego rodzaju papierkiem lakmusowym sporu między mniej i bardziej umiarkowanymi w popieraniu normalizacji stosunków z Izraelem, było wsparcie dla Hamasu w Strefie Gazy. Reżim Hosniego Mubaraka wielokrotnie musiał podejmować decyzje związane z kontrolą przemytu broni oraz innych towarów do Strefy Gazy, będąc pod presją własnej opinii publicznej oraz radykalnych Islamistów. Udaremnianie przemytu i umiarkowana postawa wobec działań Hamasu i operacji Izraela odbierana była jako wspieranie wrogiego reżimu przeciwko arabskim braciom. Należy pamiętać, iż Hamas wywodzi się bezpośrednio z powstałego w latach dwudziestych XX wieku egipskiego Bractwa Muzułmańskiego. Egipt kontrolujący granicę z Gazą musiał niejednokrotnie interweniować przeciwko próbom przemytu broni organizowanym między innymi przez rezydentury Hezbollahu w Egipcie, korzystającego ze wsparcia Iranu. Reżim H. Mubaraka, kontrolując i ograniczając wpływy Bractwa Muzułmańskiego w Egipcie, wpływał na bezpieczeństwo Izraela oraz osłabienie pozycji Iranu w regionie.

Umiarkowanie nastawione państwa arabskie zmierzały, aby władze Syrii rozpoczęły dialog z Izraelem i tym samym nie uległy wpływom radykałów oraz kół powiązanych z Teheranem. Wyrazem poparcia dialogu przez pragmatyczne państwa regionu mogą być różne formy działania na rzecz władz Autonomii na Zachodnim Brzegu. Przykładowo Jordania szkoliła bataliony palestyńskich sił bezpieczeństwa, państwa takie jak Katar wspierały inwestycje, przykładem może być budowa miasta Rawabi na Zachodnim Brzegu ${ }^{10}$.

Izrael realizował w miarę poprawną współpracę, zwłaszcza w dziedzinie bezpieczeństwa $\mathrm{z}$ jednym $\mathrm{z}$ dwóch państw arabskich, $\mathrm{z}$ którymi ma nawiązane pełne stosunki dy-

7 Turcja była główny inicjatorem tzw. Flotylli Wolności zmierzającej do przerwania blokady morskiej Strefy Gazy w maju 2010 r. Dla wielu komentatorów są to jednoznaczne gesty ze strony Turcji, świadczące o chęci odgrywania przez to państwo istotnej roli na Bliskim Wschodzie, chęć wzmocnienia pozycji w świecie Islamu, zwiększenie autorytetu wśród społeczeństw państw arabskich.

8 Zob.: The Rijadh Declaration, http://portal.mofa.gov.sa/Detail.asp?InSectionID=5447\&InNewsItemID=62681 (20.12.2011).

9 Deklaracja Bejrucka z roku 2002 została zaakceptowana podczas Szczytu Organizacji Państw Islamskich w Kuala Lumpur 1-2 kwietnia 2002 r.

10 Zob.: Building the first „Palestinian settlement”, BBC News, 27 February 2010, http://news.bbc.co.uk/2/hi/8537068.stm (20.12.2011). 
plomatyczne - Jordanią. Pokój i stabilizacja w regionie, brak konfliktów związanych z Autonomią Palestyńską leżą w centrum zainteresowania zarówno króla Abdullaha, jak i kolejnych rządów w Izraelu. Współpraca w tym zakresie była wręcz wzorcowa, niejednokrotnie służby izraelskie ostrzegały jordańskiego monarchę o istniejących zagrożeniach.

W ostatnim okresie niekorzystna sytuacja zaistniała w stosunkach Izraela z Turcją. Władze w Istambule były przez dziesięciolecia, wypróbowanym i ściśle współpracującym z Izraelem państwem muzułmańskim na Bliskim Wschodzie. Jednak relacje te uległy stopniowemu pogorszeniu po systematycznym przejmowaniu władzy w Turcji przez Partię Sprawiedliwości i Rozwoju (AKP), która jest określana mianem umiarkowanych islamistów i odsuwanie od władzy strażników świeckiego charakteru państwa tureckiego, jakimi tradycyjnie była generalicja ${ }^{11}$. Formalnie incydent z 31 maja 2010 r., gdy izraelscy komandosi przejęli kontrolę nad tureckim statkiem zmierzającym do Strefy Gazy, był jak zderzenie z górą lodową. Jednak relacje z Turcją należy traktować w kategoriach reorientacji tego państwa, rządzonego od dłuższego czasu przez AKP w kierunku relacji z najbliższym otoczeniem, a to ma charakter muzułmański.

Kreatorzy obecnej polityki zagranicznej, jednoznacznie nawiązują do historycznej tradycji Imperium Otomańskiego, wspólnoty językowej i religijnej z sąsiadami oraz geo-strategicznej pozycji państwa ${ }^{12}$. W praktyce ma to wyraz w budowie coraz to bliższych relacji z Syrią, pomimo istniejących sporów i konfliktów. W 2009 r. doszło nawet do wspólnych ćwiczeń wojskowych Turcji i Syrii, a także wzajemnych wizyt prezydentów. Rząd Turcji w umiarkowany sposób reaguje na zagrożenie związane z irańskim programem nuklearnym. Coraz bliższe relacje z Hamasem i zaangażowanie w kwestiach Palestyny, jednoznacznie świadczą o chęci Turcji zajęcia miejsca jednego z głównych graczy w tym konflikcie.

Podsumowując tą cześć można dojść do wniosku, iż z perspektywy Izraela, świeckie reżimy polityczne w odróżnieniu od muzułmańskich społeczeństw, dążyły do zakończenia konfliktu i doprowadzenia do normalizacji stosunków z tym państwem. Forpocztę stanowiły Egipt oraz Jordania, normalizacja i stabilizacja byłą na rękę również Arabii Saudyjskiej oraz innym państwom Zatoki Perskiej z uwagi na zagrożenie płynące z Teheranu, chcącego wykorzystać konflikt izraelsko-palestyński w budowie swojej strefy wpływów w regionie. Pozytywne sygnały docierały z Syrii, która w dalekosiężnych planach pokojowych, stała się obok Autonomii Palestyńskiej gwarantem porozumienia świata arabskiego i Izraela.

Najbardziej niepokojące znaki docierały tradycyjnie z Iranu oraz ze strony jego sojuszników w postaci Hamasu w Gazie oraz Hezbollahu w Libanie. Niekorzystna dla stabilizacji w regionie stała się islamizacja polityki zagranicznej Turcji i osłabienie dotychczasowych dobrych relacji z Izraelem zarówno na płaszczyźnie politycznej, jak i militarnej.

${ }^{11}$ W ostatnich wyborach z czerwca 2011 r. Partia Sprawiedliwości i Rozwoju (AKP) zdobyła władzę po raz trzeci z rzędu i posiada 326 mandatów w 550 osobowym Parlamencie. Premier Erdogan zmierza do zmiany Konstytucji i bardziej islamskiego charakteru państwa.

12 Zob.: O. Eran, Turkey and Izrael, w: Strategic Survey for Israel 2010, eds. S. Brom, A. Kurz, Tel Aviv 2010, s. 109-120. 
W tym kontekście państwa ogarnięte Arabską Wiosną Ludów, nie mające tak jak to miało miejsce w przypadku Egiptu czy Syrii, bezpośredniej granicy z Izraelem oraz niezaangażowane w konflikt poprzez bezpośrednie wsparcie dla działań terrorystycznych, nie miały większego oddziaływania na jego sytuacje strategiczną przed $2011 \mathrm{r}$. Ugrupowania i ruchy islamskie, nawet tak zdecydowanie antyizraelskie, jak Bracia Muzułmańscy i miliony ich zwolenników w Egipcie, nie odgrywały większej roli z uwagi na ich kontrolę przez rodzime reżimy polityczne. Rządzący Libią reżim M. Kadafiego, dochodząc do ugody z USA, poddając się pod wpływem państw UE dobrowolnemu rozbrojeniu z broni masowej zagłady, rezygnując z jawnego popierania ugrupowań terrorystycznych, zwalczając wpływy Al Kaidy, wpływał pozytywnie na bezpieczeństwo Izraela.

\section{ZMIANY SYTUACJI STRATEGICZNEJ IZRAELA NA SKUTEK ARABSKIEJ WIOSNY}

Postrzegając zaistniałą sytuację z perspektywy Izraela, a także konfliktu arabsko-izraelskiego, można mieć już na samym wstępie obawy, czy wręcz mniej optymistyczne, niż w Europie zdanie na temat charakteru tych zmian. „Arabska wiosna” jest odbierana w Izraelu, a także przez analityków z nim związanych, jako początek ,ery niepewności" ${ }^{\prime \prime}$. Ma to związek głównie ze zmianami dotyczącymi reżimów politycznych oraz ewentualnością dojścia do władzy, bądź współrządzenia przez wrogo nastawione do Izraela ruchy i partie islamistyczne. Negatywne konsekwencje tego typu przemian były już wcześniej obserwowane na przykładzie zmiany sytuacji w Iranie, przejęciu władzy przez Hamas w Gazie czy rządów AKP w Turcji. Nie należy również zapominać o konsekwencjach natury gospodarczej, mających istotny wpływ na równowagę sił w regionie oraz sytuację wewnętrzną w poszczególnych państwach. Aby móc na to spojrzeć z tej perspektywy, należy przeanalizować rozwój sytuacji i ewentualne konsekwencje zmian $\mathrm{z}$ tego punktu widzenia ${ }^{14}$.

Z perspektywy Izraela zmiany zachodzące w Libii, Tunezji czy Jemenie nie miały bezpośredniego wpływu na sytuację w tym państwie. Bardziej znaczące i stąd inaczej postrzegane są natomiast procesy mające miejsce w Egipcie, Jordanii, Libanie, Syrii czy Bahrajnie z uwagi na wpływy tego ostatniego na sytuację w Zatoce Perskiej oraz ogólne i potencjalne oddziaływanie tych zmian na konflikt izraelsko-palestyński. Na samym wstępie krótka analiza sytuacji w wybranych państwach regionu pod kątem społeczno-religijnym, ponieważ te kwestie są pilnie analizowane w Izraelu, ponieważ rzutują na jego bezpieczeństwo bardziej, niż wskaźniki militarne.

Rewolucje w każdym z tych państw miały inny przebieg i wydźwięk. Te na pełną skalę toczyły się w Bahrajnie, Egipcie, Jemenie, Libii oraz Tunezji, ich przebieg i cha-

13 Takiego określenia użył między innymi Ephraim Kam w swoim artykule poświeconym zmianom na Bliskim Wschodzie. Zob.: E. Kam, The New Middle East: An Era of Uncertainty, ,Strategic ASSESSMENT" 2011, vol. 14, no 1, s. 25.

${ }^{14}$ Z uwagi na to, iż bardziej szczegółowe opracowania dotyczące poszczególnych państw są częścią tego projektu, posłużę się jedynie skrótową formą przekazu. 
rakter był jednakże zróżnicowany. Państwa i społeczeństwa Zachodu, często klasyfikowały je ze swojej perspektywy, traktując i oceniając protesty z punktu widzenia demokracji, społeczeństwa obywatelskiego, walki o prawa człowieka, czy też wpływu nowoczesnych technologii na pokolenie protestu. Tymczasem protestujący akcentowali zarówno dążenie do demokracji, jak i kwestie związane z religią, tradycją, wprowadzali żądania o charakterze etnicznym czy plemiennym. W Libii początki protestów miały miejsce w regionie Cyrenajka, ponieważ lokalni przywódcy plemion wystąpili przeciwko rywalom z Regionu Trypolis. W Bahrajnie protestujący reprezentowali $80 \%$ większość szyitów, występujących przeciwko reżimowi rządzących nimi sunnitów. W protestach w Arabii Saudyjskiej uczestniczyli głównie zamieszkujący wschodnią część kraju szyici. W Syrii protestującymi są będący w większości sunnici, występujący przeciwko reżimowi reprezentującemu $12 \%$ mniejszość alawitów, ściśle współpracujących z szyickim Iranem. Niewielka bo niespełna 10 milionowa Tunezja jest jednolita religijnie (sunnici) i etnicznie (Arabowie), co ma istotne znaczenie. Należy pamiętać, iż szyici na przestrzeni wieków, zawsze stanowili w świecie arabskim ludność drugiej kategorii, upośledzoną ekonomicznie i społecznie, a nawet prześladowaną politycznie. Tymczasem po rewolucji w Iranie uzyskali oni istotne, silne wsparcie spoza świata arabskiego, w dodatku sojusznik ten posiada znacznie większą siłę polityczną i militarną, niż państwa arabskie ${ }^{15}$.

Wydarzenia „Arabskiej wiosny” uwidoczniły również problemy etniczne. Afrykę Północną licznie zamieszkują Berberowie, niejednokrotnie będący w konflikcie z dominującymi politycznie Arabami ${ }^{16}$. Inny problem etniczny to Kurdowie zamieszkujący Turcję, Irak, Iran oraz Syrię. W najsłabszym ekonomicznie, niezwykle zróżnicowanym społecznie Egipcie prześladowaną przez muzułmańską większość, mniejszością religijną są chrześcijańscy Koptowie, stanowiący 10\% mieszkańców tego kraju.

Jak widać z podanych powyżej przykładów, zachodnia, powszechna w społeczeństwach wizja jednolitego religijnie świata arabskiego jest fałszywa. $Z$ sytuacji tej zdaja sobie sprawę, ponieważ od wieków zamieszkiwali Bliski Wschód, Żydzi będący z jednej strony częścią Bliskiego Wschodu, z drugiej zaś mniejszością świata, zdominowanego przez Arabów. Różnorodność etniczna i religijna zawsze była czynnikiem, mogącym pozytywnie bądź negatywnie wpływać na sytuację $\mathrm{w}$ regionie oraz konflikt arabsko-izraelski. Izrael w swojej strategii obronnej zawsze musiał być pilnym obserwatorem, ponieważ zwaśnione strony mogły być zarówno jego sojusznikami, jak i wrogami.

Zmiany w całym świecie arabskim rozpoczęły się od protestów z grudnia $2010 \mathrm{r}$. w tunezyjskim mieście Sidi Bouzid. To w tym mieście 17 grudnia 2010 r. w akcie rozpaczy i protestu dokonał samospalenia przed budynkiem rządowym 26 letni sprzedawca owoców Mohamed Bouazizi.

Rewolucję w Egipcie zapoczątkowali, idąc za przykładem Tunezji, młodzi wykształceni i pozbawieni perspektyw mieszkańcy Kairu i Aleksandrii, symbolem stały się protesty na Placu Tahrir. Potrafili oni wykorzystać możliwości komunikacyjne i przy pomocy portalu społecznościowego Facebook sprzeciwili się ubóstwu, korupcji

\footnotetext{
15 Wyjątkiem jest w wymiarze ekonomicznym Arabia Saudyjska.

16 Przykładem może być Algieria i Maroko, natomiast w Libii oprócz Barberów są jeszcze spokrewnieni z nimi Tuaregowie, zamieszkujący również Algierię.
} 
i autorytaryzmowi rządów H. Mubaraka. Ich cele można było zawęzić do trzech punktów: rewanżu na H. Mubaraku i jego rodzinie, możliwości korzystania z większej wolności, zmiany niezwykle trudnej sytuacji ekonomicznej ludności kraju. Pozornie, bo z perspektywy turystów, najbardziej liberalny obyczajowo i religijnie Egipt, ma faktycznie najbardziej konserwatywne społeczeństwo arabskie, to z niego wywodzi się Bractwo Muzułmańskie. Zarówno w Egipcie, jak i w Tunezji Bracia Muzułmańscy od samego początku włączyli się do społecznych protestów, a następnie wykorzystali swój potencjał w działalności politycznej w nowych realiach i na nowych zasadach. Należy mieć na uwadze, iż w praktyce dotychczasowych reżimów, tłumiących i kontrolujących działania opozycji, byli oni jedyną tak silnie, oprócz struktur rodowych i plemiennych, zorganizowaną grupą społeczną zdolną do szybkiego działania w nowych realiach.

Reżim Hosniego Mubaraka był podobnie jak Jordania pod rządami króla Abdullaha z dynastii Haszemidów, sojusznikiem Zachodu i obrońcą uregulowanych stosunków z Izraelem. Trzeba pamiętać, iż nigdy taki nie był stosunek społeczeństw do Izraela. Bractwo Muzułmańskie i jego liderzy oficjalnie występowali przeciwko Izraelowi i popierali terroryzm skierowany przeciwko niemu. Tymczasem, po 30 latach wygnania 24 lutego 2011 r. triumfalnie powrócił do Egiptu duchowy przywódca Bractwa Muzułmańskiego szejk Yusuf al-Quardawi, witały go miliony Egipcjan ${ }^{17}$. Do Tunezji powrócił Rashid al-Ghanoushi, przywódca Islamskiego Ruchu al-Nahda. W rozpisanych i przeprowadzonych 23 października 2011 r. wolnych wyborach w Tunezji, niekwestionowanym zwycięzcą okazała się określana mianem umiarkowanego ugrupowania islamskiego Partia Odrodzenia (arab. Hizb an-Nahda). Był to pierwszy, jednoznaczny sygnał o islamizacji życia politycznego w Afryce Północnej.

Gdy rządzący Egiptem wojskowi zajmowali się prześladowaniem „facebookowych" przywódców protestów, aktywizowali się przedstawiciele Bractwa Muzułmańskiego. Gdy w połowie marca 2011 roku przeprowadzano referendum w sprawie zmiany konstytucji, siły umiarkowane reprezentowane między innymi przez Mohammeda El Baradei i Amr Mussę nawoływały do głosowania przeciw, a Bractwo Muzułmańskie - za. Za tą drugą opcją opowiedziało się $71 \%$ uczestniczących w referendum ${ }^{18}$. Nie powinno nikogo dziwić, iż w pierwszej turze wyborów do Parlamentu w Egipcie 27 listopada 2011 r., spektakularnym zwycięzcą została reprezentująca Bractwo Muzułmańskie Partia Wolności i Sprawiedliwości, gdyż uzyskała ona 36,6\% głosów. Łącznie egipskie partie muzułmańskie zdobyły $65 \%$ głosów z list partyjnych ${ }^{19}$. Wszystko wskazuje na to, iż podobny wynik będzie miał miejsce podczas lutowych wyborów do izby wyższej ${ }^{20}$, z dużym prawdopodobieństwem można założyć, iż prezydentem również zostanie islamistka.

17 Jest to postać wzbudzająca ogromne kontrowersje, gdyż publicznie nawoływał on do wysadzania się szahidów w Izraelu, chwalił Hitlera oraz Holokaust.

${ }_{18}$ Frekwencja wynosiła $41 \%$.

19 Pierwsza tura wyborów, przeprowadzona 28 listopada, objęła 9 z 27 prowincji Egiptu, w tym Kair i Aleksandrię.

${ }^{20}$ Chodzi o mające się odbyć wybory w 2012 r. 
Po realizacji postulatów wyborczych i aresztowaniu H. Mubaraka, rządzący dziś wojskowi wyszli naprzeciw dwóm pierwszym postulatom protestujących, ten trzeci - gospodarczy jest w dużej mierze związany z Izraelem. Niezwykle dochodowa branża turystyczna, to Półwysep Synaj, a także dochody z żeglugi przez Kanał Sueski, dochody z eksportu gazu ziemnego czy wielomiliardowa pomoc płynąca z USA są współzależne od relacji z Izraelem. Uwzględniając powyższe, obecne i przyszłe władze będą musiały działać wbrew opinii publicznej, a na rzecz zachowania porozumień z Izraelem. Czy islamiści będą działać wbrew swoim postulatom, wyborcom, arabskiej ulicy? Czy przeciwko takim zmianom po raz kolejny wystąi egipska armia? Należy pamiętać, iż w momencie nasilania się protestów w Kairze, tłum palił na ulicach flagi z Gwiazdą Dawida, personel dyplomatyczny był ewakuowany, a sama ambasada - zaatakowana przez protestujący thum.

Zapoczątkowana w Libii rebelia, mająca korzenie w Cyranejce nie miała podłoża ekonomicznego, to nie ubodzy, wykształceni, pozbawieni perspektyw podnieśli bunt. Tutaj decydował podział etniczno-plemienny, rywalizacja plemion skupionych wokół Cyrenajki z tymi z Trypolitanii, a także funkcjonujący Fezan, zamieszkały przez niearabską ludność plemion Tubu i Tuaregów ${ }^{21}$. Tak więc „rewolucja” w Libii miała i ma bardziej charakter wojny domowej, w której rebelianci, powiązani interesami etniczno-plemiennymi, wykorzystali niechęć Zachodu do M. Kadafiego, a także brak znajomości wewnętrznych realiów. Trzeba mieć na uwadze, iż reżim M. Kadafiego był w konflikcie z północnoafrykańskimi islamistami, dążącymi do utworzenia Libii rządzonej zgodnie z prawem szariatu. Jej zbrojne ramię Al-Jama'a al-Islamiyyah al-Muqatilah bi-Libya (Libyan Fighting Group - LIFG), powstało w 1995 r., to z miast Darnah oraz Bengazi rekrutowano najwięcej bojowników do Iraku i Afganistanu. Tymczasem to po przejęciu władzy przez rebeliantów już 18 listopada 2011 r. w Bengazi odbył się pierwszy od 25 lat jawny kongres Bractwa Muzułmańskiego Libii. Izrael może się obawiać, iż władza sprawowana przez rebeliantów może być bardziej nieprzewidywalna, niż Libia za rządów M. Kadafiego w ostatnich dekadach. Rebelianci są uwikłani w faktyczną wojnę domową, powiązani z LIFG, Bractwem Muzułmańskim oraz Al Kaidą Islamskiego Maghrebu. Liga Państw Arabskich poparła rezolucję nr 1973 legitymizującą akcję militarną w obronie ludności cywilnej, jednak nie poparła jej Unia Afrykańska. Z magazynów wojskowych wyciekły ogromne zapasy nowoczesnego uzbrojenia, zostały one przejęte przez uczestników konfliktu oraz najprawdopodobniej przez Al Kaidę.

Rządzący Syrią świecki reżim, do tej pory boryka się z rebelią, która wybuchła w marcu $2011 \mathrm{r}$. Trzeba mieć na uwadze, iż w swojej historii rozprawił on się w latach 1976-1982 z Bractwem Muzułmańskim, pomimo bliskich związków z Iranem, Hezbollahem i Hamasem jest on świecki, a społeczeństwo mniej konserwatywne. Z uwagi na podziały religijne, walka $\mathrm{w}$ tym państwie dotyczy nie tylko postulatów wolnościowych, ma wymiar etniczny i religijny. Alawici rządzący w Syrii, nie są przez szyitów uznawani nawet za Muzułmanów, nie ulega wątpliwości, iż zwycięstwo rebeliantów oznaczać może w praktyce dominację islamskich fanatyków związanych z sunnicką

21 Społeczność Tuaregów, prześladowana w sąsiednich krajach, a bardzo liczna, bo 5 milionowa była zawsze sprzymierzeńcem M. Kadafiego, służąc w jego formacjach paramilitarnych. 
większością, niemających żadnego pojęcia o demokracji, prawach człowieka lub powolnej drodze ku demokratycznym przemianom. W konflikcie mediatorem jest Liga Państw Arabskich reprezentująca w większości sunnickie społeczeństwa państw arabskich, stronnikiem jest Iran popierający Assada, a skład etniczno-religijny Syrii to potencjalna „tykająca bomba” (13\% alawici; $10 \%$ chrześcijanie; $10 \%$ Kurdowie i ponad $60 \%$ sunnici). Graczem jest również Rosja posiadająca swoją bazę morską w syryjskim porcie Tartus oraz ChRL, dla której niezakłócone dostawy irańskiej ropy i gazu są kwestią bezpieczeństwa narodowego. Dlatego oba te mocarstwa blokują rezolucję Rady Bezpieczeństwa ONZ, występującą przeciwko Basharowi al-Assadowi. Władze Izraela pilnie obserwują sytuację w Syrii i są świadome, iż jakiekolwiek zmiany zachodzące w Syrii bezpośrednio mają i będą miały wpływ na bezpieczeństwo Izraela. Bardziej korzystna z punktu widzenia jego interesów, była sytuacja już znanego wroga, stopniowo podchodzącego do kwestii normalizacji wzajemnych relacji, niż nieznanego. Lepsze znane zło, niż nieprzewidywalny, wrogi postasadowski rząd z Bractwem Muzułmańskim na czele. Bashara al-Assada popiera związany z nim Iran, Irak odmawiający nałożenia sankcji na Syrię, oraz podobnie postępujący Liban. Kraje BRIC są zasadniczo nieugięte w swoim stanowisku: kryzys w Syrii powinni rozwiązać sami Syryjczycy.

W graniczącej i mającej uregulowane relacje z Izraelem Jordanii nie doszło do procesów mających charakter rewolucji, tak jak to miało miejsce w Egipcie, Tunezji, Libii, Syrii czy Jemenie ${ }^{22}$. Co nie oznacza, iż nie występuje stan pewnego zagrożenia, od dłuższego czasu w Królestwie Jordanii ma miejsce krytyka rodziny królewskiej oraz próba dojścia do władzy palestyńskiej większości w tym kraju. Na sytuację w Jordanii może mieć wpływ wycofanie się ostateczne USA z Iraku i możliwość większej penetracji tego kraju przez wysłanników Teheranu. Należy pamiętać, iż po upadku reżimu S. Husajna bardzo duża grupa Irakijczyków osiedliła się w Jordanii, a o Ammanie mówi się potocznie, jak o „małym Bagdadzie”.

Jeśli chodzi o bogaty Półwysep Arabski z Arabią Saudyjską na czele, to państwa tego obszaru utrzymują dobre stosunki z Zachodem i są jego sojusznikami w walce z Al Kaida, gdyż jest ona ideową konkurencją dla wahabbickiej dynastii Saudów. Nie oznacza to jednak mniejszego fundamentalizmu. Szyici w Arabii Saudyjskiej, Bahrajnie, Jemenie, Katarze są wspierani przez Iran. Szyicka rebelia w Bahrajnie była, zdaniem Saudów, wspierana i wywołana przez Iran. Iran oraz Szyici są więc wrogiem Arabii Saudyjskiej oraz innych państw z nią sprzymierzonych. Niepokoje wywołane przez szyitów, wzmacniają więc pośrednio Iran, otwarcie występujący przeciwko Izraelowi i programowo głoszący chęć zniszczenia Izraela.

Newralgiczna pozycja małego Bahrajnu i stabilność silnie powiązanego z USA państwa, ma istotny wpływ na bezpieczeństwo Izraela. Stany Zjednoczone posiadają w nim jedną ze swoich najważniejszych baz wojskowych w tym regionie świata. Napięcie w Bahrajnie ma związek zarówno z sytuacją wewnętrzną - mniejszość sunnicka, rządzi szyicką większością, jak i konfliktem pomiędzy Arabią Saudyjską i Iranem. Zachowanie istniejącego status quo w Bahrajnie nie jest obojętne Arabii Saudyjskiej, Ka-

${ }^{22}$ Charakterystyczne, że bardziej odporne na rewolucje okazały się monarchie. 
tarowi, Kuwejtowi, Omanowi i Zjednoczonym Emiratom Arabskim, a także odległemu Izraelowi.

\section{KONSEKWENCJE PRZEMIAN W REGIONIE DLA KONFLIKTU ARABSKO-IZRAELSKIEGO - SZANSE I ZAGROŻENIA}

Zmiany w regionie z 2011 r. obrazują wszystkie gospodarcze, społeczne i polityczne problemy obnażone w ciagu ostatnich dwudziestu-trzydziestu lat, nie tylko w tej części świata, przez globalizację. Czynnikiem determinującym rewolucję były młode, pozbawione perspektyw warstwy społeczne, których miliony wypełniły ulice Kairu, Tunisu i innych miast Bliskiego Wschodu. Obalenie dotychczasowych reżimów nie jest gwarantem zmiany sytuacji społecznej i ekonomicznej w państwach arabskich ${ }^{23}$.

Bardzo istotne jest miejsce oraz pozycja armii w toczącym się procesie przemian. Zarówno w Egipcie, Tunezji, Libii, jak i pozostałych państwach regionu, demonstranci zmierzali do obalenia rządów. Natomiast tylko w Libii, na skutek tego, iż armia i siły bezpieczeństwa były jednoznaczną stroną konfliktu, doszło do odsunięcia od władzy wojskowych. Zarówno w Tunezji, jak i w Egipcie armia pozostała u władzy, formalnie do czasu demokratycznych wyborów. To od zachowania armii i postawy całej struktury bezpieczeństwa, będzie zależała przyszłość Egiptu.

Należy zwrócić uwagę na fakt, iż wraz z upadkiem dotychczasowych władz, dochodziło do niepowodzeń rządzących, związanych z nimi partii politycznych. Partie, które na początku swojej drogi, zapowiadały zmiany o charakterze społecznym, poprzez legitymizacje reżimów i zaczęły reprezentować jedynie wąskie elity władzy, traciły zupełnie w oczach społeczeństwa. Tak sytuacja dotknęła Zgromadzenie Demokratyczno-Konstytucyjne, partię obalonego reżimu prezydenta Ben Alego, została ona zawieszona decyzją Ministra Spraw Wewnętrznych Tunezji w lutym 2011 roku² ${ }^{24}$. Podobny los spotkał Narodową Partię Demokratyczną w Egipcie - byłe ugrupowanie rządzące w tym państwie, której liderem był Hosni Mubarak ${ }^{25}$. Lukę po tych ugrupowaniach wypełniły dziesiątki nowych partii, szczególnie silnymi okazały się partie religijne - islamskie. Rodzi się zatem praktyczne pytanie dotyczące faktycznego wpływu Radykalnego Islamu dla tak ważnego z punktu widzenia konfliktu arabsko-izraelskiego sąsiada, jak Egipt pod rządami Bractwa Muzułmańskiego?

Nie ulega wątpliwości, iż Bracia Muzułmańscy w Egipcie, wzmocnieni przez różnego rodzaju swoje odłamy w innych krajach arabskich mogą ubiegać się o rolę lidera duchowego i zająć dotychczasowe miejsce Iranu. Nie należy zapominać, iż zawsze byli oni w sporze z szyickim reżimem rządzonym przez Ajatollahów. Pytanie brzmi, czy będą oni popierać antyizraelski radykalizm, wbrew własnym interesom eko-

${ }^{23}$ Stosunkowo najłatwiej będzie w tym względzie w Tunezji, gdyż jest tam relatywnie nieduże (9 800000 mieszkańców), dość dobrze wykształcone, nie znajdujące się na pograniczu katastrofy ekonomicznej społeczeństwo.

${ }^{24}$ Decyzją Sądu w Tunisie została ona rozwiązana w 9 marca $2011 \mathrm{r}$.

25 Partia ta założona w 1978 r. przez Anwara Sadata, została decyzją Sadu w Kairze rozwiązana 16 kwietnia $2011 \mathrm{r}$. 
nomicznym? Czy można mówić, iż zmianom uległa strategia ruchu, czy też jedynie jego doraźna taktyka, związana z możliwością legalnego funkcjonowania po obaleniu dotychczasowego reżimu? Postulat strategiczny Bractwa Muzułmańskiego, to odbudowa kalifatu obejmującego cały świat arabski, wprowadzenia w nim prawa szariatu oraz wojna z Izraelem w celu jego ostatecznego zniszczenia. Radykalne, silne rządy w Egipcie mogą starać się zjednoczyć pod swoim duchowym przywództwem, cały wrogi Izraelowi świat arabskiej ulicy, wbrew woli rządzących nimi reżimów politycznych. Już teraz pojawia się wiele spekulacji na temat tego, iż znaczna część obecnych protestów na Bliskim Wschodzie nie jest spontaniczna, lecz planowo podsycana przez Bractwo Muzułmańskie i wspierającą je telewizję Al Jazeera.

Jeszcze przed ewentualną utratą kontroli przez wojskowych, w Egipcie w znaczącym stopniu został osłabiony system kontroli Półwyspu Synaj. Wzrasta przemyt broni i innych materiałów do Strefy Gazy, narasta zagrożenie infiltracji Izraela z tego obszaru, należy pamiętać, iż było to znaczące zjawisko przed podpisaniem porozumień pokojowych. W ostatnim okresie, pomimo znacznego zagrożenia ze strony zarówno Hezbollahu atakującego z terytorium Libanu, jak i Hamasu ze Strefy Gazy, Izrael mógł pozwolić sobie na prowadzenie dużych operacji militarnych takich, jak operacja „Płynny Ołów” na przełomie 2008/09, mając pewność braku reakcji ze strony Egiptu. W przypadku radykalnej zmiany polityki taka sytuacja może ulec zmianie.

Przy okazji omawiania zmian związanych z ewentualnymi wpływami Bractwa Muzułmańskiego, nie należy zapominać o odnawianiu i wzroście jego wpływów w Libii. Teoretycznie, przy scenariuszu rozbicia Libii i kontynuowania w niej wojny domowej może dojść do kontroli przez Bractwo Muzułmańskie złóż ropy naftowej i jakiejś formy aneksji wschodniej Libii. Co z perspektywy Izraela wzmocni jeszcze bardziej stan jego zagrożenia, potencjalny wróg wzmocni swoją kondycję ekonomiczną, będzie mógł pozwolić sobie na wzrost radykalizmu w odniesieniu do Izraela.

Postrzegając problem bezpieczeństwa z perspektywy zmiany strategicznej mającej miejsce, a także jej ewentualnej konsekwencji dla polityki obronnej Izraela. Musi to mieć istotne znaczenie dla zmian polityczno-budżetowych, znaczących w porównaniu z ostatnimi 32 latami stabilizacji. Zdaniem analityków izraelskich, będzie to musiało odzwierciedlać się we wzmocnieniu potencjału morskiego, lotniczego i lądowego armii izraelskiej, a także zapasów strategicznych uzbrojenia, części zamiennych i paliw $^{26}$. Logiczną i praktyczną konsekwencją tego typu koniecznych decyzji będzie musiało być wzmocnienie budżetu obronnego i osłabienie wzrostu gospodarczego w Izraelu. Oczywiście będzie to miało charakter procesu, radykalne zmiany w Egipcie nie nastąpią z dnia na dzień, Izrael będzie miał czas na obserwację i kosztowne przygotowania.

Na przełomie roku 2011 i 2012 cały czas trwająca rewolta w Syrii przy zaangażowaniu Ligi Państw Arabskich i narastaniu aktów o charakterze terrorystycznym w Damaszku, wskazuje na ciagły brak rozstrzygnięć. Z punktu widzenia Izraela, pozostanie przy władzy, osłabionego obecną rebelią Bashara al-Assada, będzie oznaczało wzrost jego zainteresowania sytuacją wewnętrzną oraz ratowaniem legitymizmu na

${ }^{26}$ Zob.: G. Eiland, The Upheavals in The Middle East and Israel's Security, „Strategic ASSESSMENT" 2011, vol. 14, no 2, s. 9. 
arenie międzynarodowej. Co powinno osłabić jego wpływy w Libanie, możliwości oddziaływania na sytuację w tym kraju, wspieranie bezpośrednie, bądź pośrednie wrogiego dla Izraela Hezbollahu. W tych okolicznościach Izrael nie powinien spodziewać się aktywności Syrii w szukaniu militarnej konfrontacji z Izraelem. Jest to jeden z możliwych scenariuszy, inny może mieć związek ze zdecydowanym zwycięstwem Bashara al-Assada przy zaangażowaniu w wewnętrznym konflikcie Iranu, który postąpi podobnie, jak analogicznie Arabia Saudyjska w Bahrajnie. Przy tym wariancie Izrael może się spodziewać realizacji antyizraelskiej polityki Iranu, przy znacznym zaangażowaniu Syrii i odejściu od jakichkolwiek możliwości rozwiązania konfliktu na drodze pokojowej. Trzeci scenariusz ma związek z upadkiem reżimu B. al-Assada i uwikłaniem Syrii w falę konfliktów wewnętrznych o charakterze wojny domowej i niestabilności. Może w tym przypadku powtórzyć się wariant Iracki, wzrostu wpływów Iranu i grup przez niego popieranych, dążących do konfrontacji z Izraelem. Syria sama w sobie będzie mniejszym militarnym zagrożeniem dla Izraela, natomiast większe konsekwencje będą dotyczyły braku stabilności na granicy z Libanem i konfrontacji z Hezbollahem. Czwarty wariant może polegać na zwycięstwie opozycji sunnickiej i powstania radykalnego antyizraelskiego rządu, zdominowanego przez proarabskich sunnitów. Taki rząd utraci wprawdzie poparcie Iranu, może on być jednak bardziej agresywny w sporze izraelsko-syryjskim, dotyczącym procesu pokojowego. Może on dążyć do zdecydowanej konfrontacji militarnej z Izraelem. Oczywiście nie można wykluczyć, iż w zlaicyzowanej Syrii dojdzie do powstania jakiejś formy demokratycznego, sprzyjającego Zachodowi rządu. Nie musi to oznaczać, iż taki reżim będzie bardziej skłonny do kontynuowania procesu pokojowego, zwłaszcza, iż uzależniony on jest od opinii i nastawienia całego świata arabskiego. Żaden ze scenariuszy nie pogarsza zdecydowanie sytuacji militarnej Izraela. Paradoksalnie jednak pozostanie u władzy, osłabionego wewnętrznym konfliktem B. al-Assada, może osłabić zagrożenie z tego kierunku i skłaniać do większego kompromisu na drodze negocjacji pokojowych.

Scenariusze dotyczące Syrii, pośrednio dotyczą sytuacji na granicy z Libanem i pozycji Hezbollahu w tym kraju. Rewolucje związane z „Arabską wiosną” nie miały charakteru rewolucji islamskiej z roku 1979, jaka nastąiła w Iranie. Zarówno Syria, jak i Iran mogą chcieć wykorzystać Hezbollah do wzmocnienia stanu konfrontacji i napięcia na granicy z Izraelem. Wewnętrzna pozycja Hezbollahu w samym Libanie, również może skłaniać to ugrupowanie do militarnej konfrontacji. Izrael musi być przygotowany na taki scenariusz zarówno militarnie, jak i społecznie, co oznacza przygotowanie społeczeństwa na ewentualną, kolejną wojnę na granicy z Libanem.

W relacjach Izraela i Jordanii najgorszym scenariuszem może być upadek monarchii i zdobycie władzy przez zamieszkującą Jordanię większość palestyńską. Zmieniłoby to całkowicie dotychczasowe scenariusze dotyczące procesu pokojowego. Należy pamiętać o tym, iż Izrael od dziesięcioleci współpracował i współpracuje z Jordanią w dziedzinie zapewnienia bezpieczeństwa na granicy. Miało to miejsce również przed podpisaniem układu pokojowego, gdyż obie strony postrzegały Palestyńczyków, jako potencjalne zagrożenie i czynnik niestabilności na granicy.

Bahrajn i próba obalenia rządów sunnitów przez szyicką większość popieraną przez Iran, zasiał poczucie niestabilności w tej części Półwyspu Arabskiego. Wzmocnił również wpływy Al Kaidy w tej części świata, gdyż ta walczy z obecnością niewier- 
nych - Amerykanów na ziemiach Islamu. Gdyby w wyniku tego doszło do zagrożenia obecności militarnej USA w regionie, w znacznym stopniu osłabiłoby to pozycję strategiczną Izraela i przyczyniało do zaostrzenia konfliktu izraelsko-arabskiego.

Wszystkie opisane powyżej procesy mają i mogą mieć w przyszłości niekwestionowany wpływ na konflikt izraelsko-palestyński. Mają dzisiaj, gdy wskażemy na coraz mniejszą kontrolę Egiptu na granicy ze Strefą Gazy oraz osłabienie relacji w dziedzinie bezpieczeństwa z Państwem Izrael. Podobnie jeżeli chodzi o naciski na stronę palestyńską w dziedzinie dialogu oraz chęć kompromisu z Izraelem. Mogą mieć jeszcze większy negatywny wpływ, gdy dotychczasowe reżimy w państwach sąsiadujących Egipcie, Syrii, Jordanii zostaną zastąpione przez rządy ugrupowań islamistycznych np. Bractwa Muzułmańskiego, gdyż programowo są one antyizraelskie. Bardzo dużo zależy i będzie zależało od tego, czy w regionie na skutek zmiany sytuacji w Syrii oraz Libanie osłabnie pozycja Iranu, czy będzie on nadal za pośrednictwem Hamasu i Hezbollahu podsycał konflikt? Czy w krajach Zatoki Perskiej oraz w świecie arabskim wzmocni się antyirańska koalicja? Czy wreszcie starająca się o wzmocnienie swoich wpływów w regionie, aktywnie po stronie antyizraelskiej będzie działać Turcja i w ten sposób kreować sytuację na Bliskim Wschodzie?

Nastroje społeczne oraz intencje protestujących wcale nie muszą oznaczać akceptacji demokracji w Zachodnim stylu, trzeba pamiętać, iż w Egipcie czy Tunezji początki i trzon protestów stanowili młodzi wykształceni mieszkańcy miast. Demokracja oznacza decyzje większości, a te mogą oznaczać wzrost sympatii dla ekstremizmów, których wyrazem mogą być rosnące wpływy Al Kaidy. Nowa sytuacja może być korzystna dla tej organizacji, gdyż programowo zmierzała ona i zmierza do władzy na zasadach Isla$\mathrm{mu}$, temu miało i ma służyć obalenie laickich reżimów. Dodatkowym argumentem dla rozwoju sytuacji w tym kierunku mogą być nowe możliwości związane z wojną domową w Libii i możliwościami zdobycia broni. Tego typu scenariusz występował już wcześniej w Iraku po obaleniu S. Hussajna. Korzystną możliwością może być oficjalne funkcjonowanie tej organizacji w życiu publicznym państw, rekrutacja zwolenników, szkolenie i realizowanie długofalowej strategii. Zwłaszcza, iż nowe władze w Egipcie i Tunezji oficjalnie deklarują demontaż służb bezpieczeństwa kojarzonych z byłymi reżimami, głównych wrogów Al Kaidy w tych państwach ${ }^{27}$. Liderzy tej organizacji w swoich reakcjach na wydarzenia w regionie, potwierdzające pośrednio błędność własnej polityki w dążeniach do zbrojnego obalenia reżimów, podkreślają, iż niedługo może dojść do drugiej rewolucji. Jej podłożem będzie rozczarowanie i niezadowolenie z niedostatecznych zmian, zwłaszcza w obszarze polepszenia sytuacji społeczno-ekonomicznej ${ }^{28}$.

Osłabienie rządów w państwach odczuwających skutki Arabskiej wiosny tj. Jemenie, może stwarzać większe możliwości dla działalności organizacji. Wielu uwięzio-

27 Zob.: Egypt's Hated State Security Agency Dismantled, CBS News, 15 March 2011, http://www.cbsnews.com/stories/2011/03/15/501364/main20043438 (21.12.2011).; Tunisia Disbands State Security, al-Jazeera, 8 March 2011, http://english.aljazeera.net/news/africa/2011/03/ 2011382051641249.html (21.12.2011).

${ }^{28}$ Zob.: J. C. Zarate, D. A. Gordon, The Battle for Reform with Al-Qaeda, „Washington Quarterly" 2011, vol. 34, no 3. 
nych wcześniej jej aktywistów wyszło na wolność w Tunezji, Libii, Egipcie. W Libii Al Kaida była i jest sprzymierzeńcem rewolucjonistów, co może rodzić określone skutki natury praktycznej. Niestabilność w regionie może służyć wzrostowi zainteresowania organizacją w społeczeństwach oraz sprzyjać logistycznie i organizacyjnie jej rozwojowi i rozprzestrzenianiu wpływów.

\section{QUO VADIS - PRÓBY ODPOWIEDZI NA STRATEGICZNE PYTANIA IZRAELA}

Z punktu widzenia Izraela, na bazie dotychczasowych doświadczeń, trudno postrzegać „Arabską wiosnę” z perspektywy anglosaksońskiego entuzjazmu dla przemian w tym regionie. Demokracja postrzegana przez pryzmat wyborów, nie musi wcale oznaczać demokracji i drogi do pokojowych rozwiązań oraz dialogu. Nie oznacza to, iż demokratyczne procesy w świecie arabskim nie są postrzegane pozytywnie. Hipotetyczne powstanie wokół Izraela społeczeństw i państw demokratycznych powinno oznaczać większą akceptację i zrozumienie dla samego Izraela oraz jego racji i dylematów w dziedzinie bezpieczeństwa, związanych z trwającym od kilkudziesięciu lat konfliktem. Oceniając umiarkowany optymizm władz Izraela, trzeba mieć na uwadze, iż władze oraz społeczeństwo tego państwa są doświadczone wojną i konfliktem z sąsiadami od 14 maja 1948 r. Politycy oraz znaczna część Żydów stanowiących trzon społeczeństwa izraelskiego, wywodzi się z krajów arabskich, stąd znajomość specyfiki kulturowej i społecznej, realizm w ocenie zmian mających miejsce w regionie jest bardziej umiarkowany, niż w świecie Zachodu. Izrael musiał i musi postrzegać swoją strategiczną sytuację $\mathrm{w}$ obszarze bezpieczeństwa $\mathrm{z}$ perspektywy misternie układanych wieloelementowych puzzli. Wydarzenia arabskiej wiosny oraz sytuacja ją poprzedzająca dotycząca Bliskiego Wschodu, w znacznym stopniu skłania Izrael do tworzenia nowej układanki, jeszcze bardziej misternej i wymagającej większej uwagi, niż poprzednia.

Konflikt między państwami regionu, ich rywalizacja, zaangażowanie, skupienie na swoich wewnętrznych problemach, zawsze w dziejach współczesnego Izraela oznaczało mniejsze zagrożenie, ponieważ potencjalni wrogowie byli zajęci swoimi sprawami. Parząc z tej perspektywy, na długo przed arabską wiosną zaczęła niknąć korzystna dla Izraela sytuacja rywalizacji, czy otwartego konfliktu między Iranem i Irakiem. Przewagę w nim uzyskał wrogo nastawiony do Izraela Iran, a konsekwencją wycofania się USA z Iraku może być rosnący wpływ władz Teheranu w Iraku. Szyicki Iran może teraz bardziej oddziaływać na Jordanię oraz Liban, co negatywnie wpływa na strategiczną sytuację Izraela.

W ciągu dziesięcioleci przeplatanych wojnami, Izraelowi udało się zawrzeć porozumienia pokojowe z Egiptem oraz Jordanią, a w 2007 r. Liga Państw Arabskich zaakceptowała możliwość całkowitej normalizacji stosunków z tym państwem. Paradoksalnie, gwarantami procesu pokojowego były i są niedemokratyczne, w rozumieniu Zachodu, reżimy państw regionu. Ostatnie lata pokazały, iż coraz bardziej przeciwko Izraelowi, w regionie angażuje się jego dotychczasowy, wieloletni sojusznik w świecie Islamu - Turcja. Turcja będąca przeciwwagą dla Syrii, wspierająca izraelskie działania do- 
tyczące Iraku oraz Iranu, traktująca te państwa również z perspektywy własnej polityki bezpieczeństwa to był bardzo istotny element dotychczasowej, strategicznie ważnej układanki. Tymczasem laicka Turcja, kontrolowana przez armię, staje się coraz bardziej islamska, poprzez wieloletnie rządy Partii Sprawiedliwości i Rozwoju (AKP) pod przywództwem Recepa Tayyipa Erdogana. Nie jest to dobrym sygnałem dla Izraela, ponieważ komplikuje to jego sytuację strategiczną. Współpraca wojskowa obu państw, była niezwykle istotna z punktu widzenia bezpieczeństwa Izraela. Tureckie samoloty, tej samej generacji, co izraelskie w swoich systemach obronnych miały wpisane kody rozpoznawania „swój”, nie „obcy”. W operacjach militarnych z użyciem lotnictwa, Izrael mógł liczyć na udostępnianie tureckiej przestrzeni powietrznej. Współpraca wywiadowcza była na poziomie wręcz modelowym. Oficjalnie zdobywające władzę w Tunezji oraz Egipcie partie islamistyczne, opowiadają się publicznie za nowoczesnym i umiarkowanym Islamem, a wzorem dla nich jest Turcja. Jednak paradoksalnie, z perspektywy Izraela, ten umiar oznacza zaostrzenie wzajemnych relacji.

Dużą niewiadomą jest dzisiaj dla Izraela polityka Turcji w regionie. Od tego czy tureckie władze będą dążyły do uczynienia z Turcji lidera islamskiej koalicji przeciwko Izraelowi, zależy wzrost zagrożenia dla Izraela. Od wzrostu wpływów Turcji, jej chęci dominacji oraz polityki Iranu uzależniony jest swoisty sojusz z Arabią Saudyjską przeciwko władzom w Teheranie. Należy przy tym pamiętać, iż władze Turcji są żywotnie zainteresowane koalicją z Iranem i Syrią przeciwko Kurdom, których sytuacja oraz wpływy zdecydowanie uległy poprawie po obaleniu reżimu Saddama Husajna w Iraku. Irak jest dzisiaj w faktycznej strefie wpływów Iranu, a iracki Kurdystan z jego szeroką autonomią budzi niepokoje w Turcji. Możliwy jest sojusz, handel wymienny Turcji z Iranem w celu osłabienia Kurdów w Iraku. Izrael zawsze w polityce związanej ze swoim bezpieczeństwem $\mathrm{w}$ regionie, pilnie obserwował i niejednokrotnie wspierał mniejszości we wrogo nastawionych do niego państwach regionu, tak może być również dzisiaj w przypadku Kurdów. Takie sygnały są wysyłane z Tel Awiwu do Istambułu, bo to leży w strategicznym interesie Izraela.

Polityka Turcji jest zdecydowanie ambiwalentna, mniej obliczalna obecnie, niż pod koniec XX wieku. Wystarczy wziąc pod uwagę jej odmowę współpracy z USA w momencie, gdy rozpoczynały się działania w Iraku, reakcję na możliwość przekazania Cyprowi przewodnictwa w UE, zaangażowanie w Konwój Pokoju skierowany do Strefy Gazy, czy zaprzestanie współpracy militarnej z Izraelem. Trudno jest jednoznacznie ocenić, czy chodzi tu o motywacje ideologiczne, strategiczne, a może interesy ekonomiczne w takiej polityce Turcji. Dla Izraela jest to powód do wzmożonego niepokoju, ma również konsekwencje o charakterze strategicznym.

Przewidywane, po zakończeniu ostatecznie procesu wyborczego zwycięstwo Bractwa Muzułmańskiego w Egipcie, to dla Izraela diametralna zmiana sytuacji. Musi ona w najbliższej przyszłości rzutować na zmianę strategiczną i presję na wzrost PKB przeznaczanego na cele obronne, co będzie wywierało wpływ na sytuację wewnętrzną w samym Izraelu. Trudno spodziewać się, by w Egipcie sam fakt demokratycznych wyborów zmienił sytuacje społeczną i ekonomiczną tego kraju. Egipt, podobnie jak Tunezja około $16 \%$ PKB czerpie z turystyki, narastanie nastrojów antyzachodnich i antychrześcijańskich, jak to ma miejsce w przypadku Egiptu, może oznaczać pogorszenie sytuacji. Entuzjastyczny w odbiorze „Arabskiej wiosny”, pogrążony kryzysem Zachód, 
nie jest zdolny do poparcia ekonomicznego zmian demokratycznych, na taką skalę i w taki sposób, jak to miało miejsce w przypadku Europy Środkowej i Wschodniej. Sumy transferowane w formie wielomiliardowej pomocy dla Egiptu i Tunezji z Międzynarodowego Funduszu Walutowego oraz fundusz stabilizacyjny ustanowiony przez Arabię Saudyjską w wysokości 20 miliardów dolarów na wsparcie Omanu oraz Bahrajnu, nie dają gwarancji pozytywnych zmian. Kwestią istotną jest przeznaczenie tych funduszy oraz stopień ich marnotrawienia. Nastroje mogą się jedynie radykalizować, co w praktyce może oznaczać wykorzystywanie antyizraelskich haseł, jako swoistego rodzaju katalizatora. Według danych szacunkowych w ciagu zbliżającej się dekady należałby stworzyć w państwach arabskich 100 milionów nowych miejsc pracy. To one mogłyby być gwarantem demokratycznych przemian. Pozostają pytania: jak uzyskać taki efekt i skąd wziąć środki na realizację zamierzeń, skoro świat jest w kryzysie? Te pytania nie są ważne tylko dla samych zainteresowanych, są one o strategicznym znaczeniu dla Izraela.

Władze Izraela muszą brać pod uwagę, iż każdą możliwą sytuację, do odwrócenia uwagi świata od swojego programu nuklearnego będzie wykorzystywał Iran. Część przejawów „rewolucji” związanych z arabską wiosną w państwach Bliskiego Wschodu, było inspirowanych przez władze w Teheranie. Iran uruchamiając swoich sojuszników w postaci Hamasu i Hezbollahu, prowokując Izrael do reakcji militarnych, wzmacniał zawsze nastroje antyizraelskie wśród społeczeństw państw arabskich. Chcąc osłabić rządy Egiptu czy Arabii Saudyjskiej, może użyć tego mechanizmu w każdej chwili, co dla Izraela oznacza konieczność działań militarnych na kilku frontach.

Wielką niewiadomą dla całego regionu, jest sytuacja w Libii, historycznie podzielonej, w której tysiące ludzi są w posiadaniu nowoczesnej broni z magazynów byłego reżimu. A także potencjału w postaci przejęcia kontroli nad aktywami płynącymi z ropy naftowej. Broń płynie szerokim strumieniem do państw ościennych, wzmacnia napięcie. $Z$ punktu widzenia Izraela oraz fundamentalnego bezpieczeństwa, pytaniem jest jaka część z tych arsenałów może dostać się w ręce terrorystów z Hamasu czy Hezbollahu? Czy nie nasili to militarnej konfrontacji i nie osłabi chęci dialogu?

Wydarzenia „Arabskiej wiosny” wskazują Izraelowi na niepokojące sygnały płynące ze Stanów Zjednoczonych oraz UE, dotyczące ich zaangażowania w regionie. Przykładem mogą tu być różne standardy postrzegania wydarzeń w Libii oraz Syrii. Znamienna jest tu rezolucja nr 1973 Rady Bezpieczeństwa ONZ w sprawie Libii i jej konsekwencje w postaci militarnego zaangażowania państw zachodnich po stronie libijskich rebeliantów. Gdy 17 marca 2011 r. rezolucja została przyjęta, liczba ofiar po stronie protestujących Libijczyków nie była mniejsza niż Syryjczyków, pomimo tego Zachód nie zaangażował się tam i liczba ofiar systematycznie wzrasta. Stany Zjednoczone, ich możliwości oddziaływania w regionie ewidentnie słabną jest to również niepokojący sygnał dla Izraela. Namacalnym dowodem osłabienia może być sytuacja w Iraku i faktyczny brak możliwości USA w dziedzinie osłabienia wpływów Iranu w tym państwie. Generalizując Afganistan, Irak, Syria, Pakistan wskazują na to, iż polityka administracji USA jest mało efektywna. Zarówno sojusznicy, jak i rywale przekonali się, iż wola USA czy też ich życzenia, nie są na Bliskim Wschodzie tak skrupulatnie spełniane, jak w czasach minionych.

Coraz silniejszym graczem międzynarodowym staje się Liga Państw Arabskich, która wyraziła poparcie dla rezolucji nr 1973, a obecnie jest organizacją monitorującą 
sytuację w Syrii. Dlatego dla Izraela bardzo istotne znaczenie ma to, kto po arabskiej wiośnie będzie dominował w LPA oraz czy będą kontynuowane dotychczasowe propozycje dotyczące uregulowania konfliktu arabsko-izraelaskiego i ostatecznego uznania tego państwa. Dotychczasowe propozycje dotyczące normalizacji płynęły od dynastii Saudów, zainteresowanych podobnie, jak Izrael zahamowaniem radykalizmu i utrzymaniem status quo ${ }^{29}$. Z perspektywy monarchii, bezpieczeństwo było obwarowane porozumieniem z USA w ramach pakietu „ropa w zamian za stabilność i bezpieczeństwo”. Dzisiejsza sytuacja podważa istotę tego porozumienia. Polityka Stanów Zjednoczonych, takie sygnały, jak wycofanie się z Iraku (co spowodowało przybliżenie wrogiego Iranu do granic Arabii Saudyjskiej), konstatowanie i naciski na demokratyczne reformy w Arabii Saudyjskiej czy Bahrajnie, dialog z Bractwem Muzułmańskim w Egipcie - to wszystko przekonuje, iż nastaje era post-amerykańska i w sprawach bezpieczeństwa trzeba liczyć na siebie. Z tym wiążą się wielomiliardowe zakupy nowoczesnego uzbrojenia przez Arabię Saudyjską oraz nastawienie na realizację własnej polityki, związanej ze zbliżeniem z regionalnymi mocarstwami tj. ChRL, Indiami czy Pakistanem $^{30}$. Izrael musi postrzegać rozwój sytuacji z dwojakiej perspektywy: Po pierwsze niebezpieczne z punktu widzenia Izraela może być w tym kontekście poczucie osamotnienia Arabii Saudyjskiej oraz próby realizacji własnego programu nuklearnego w celu złagodzenia dysproporcji z Iranem, realizującym własny program atomowy. Wpłynęłoby to na regionalny, nuklearny wyścig zbrojeń w świecie społeczeństw wrogo nastawionych do Izraela. Po drugie, realizacja regionalnych aspiracji Arabii Saudyjskiej, wzmocnienie współpracy państw Zatoki Perskiej, dążenie do wzrostu jej wpływów w Egipcie przy pomocy wielomiliardowego wsparcia, to budowa czegoś na kształt sunnickiego NATO pod jej przewodnictwem, celem zasadniczym jest w tym przypadku Iran, wspólny wróg Saudyjczyków i Izraela, co może wpłynąć na zbliżenie strategicznych interesów tych państw ${ }^{31}$.

Zarówno Arabia Saudyjska, jak i Izrael są żywotnie zainteresowane utrzymaniem strategicznej równowagi $\mathrm{w}$ regionie. Nie jest w ich interesie ani dominacja Iranu, ani też Turcji, co ma dla Izraela konsekwencje, związane z sytuacją w Libanie oraz jego granicą kontrolowaną w praktyce przez Hezbollah. Może ona być związana z zachowaniem dotychczasowego status quo w tym kraju i znaczącymi wpływami związanego z Iranem Hezbollahu, innym scenariuszem jest wzrost napięcia na osi Iran-Syria-Hezbollah, bądź przejęciem tej strefy wpływów przez Turcję kosztem Syrii i Iranu. Dla Izraela oraz dla stabilizacji regionalnej korzystne byłoby przyjęcie przez Liban pro-saudyjskiej orientacji, dostanie się w jej strefę wpływów, ma to uwarunkowania związane z sytuacją w Syrii.

${ }^{29}$ W sytuacji Arabii Saudyjskiej jest również Jordania, a także inne monarchie Zatoki Perskiej. Dla tych państw utrzymanie status quo jest ich żywotnym interesem. Odwrotnie patrzy na te zmiany Iran, a także Turcja, gdyż obu tym państwom zależy na przeorganizowaniu dotychczasowego układu sił $\mathrm{w}$ regionie.

${ }^{30} \mathrm{~W}$ chwili obecnej największym konsumentem saudyjskiej ropy naftowej nie są Stany Zjednoczone, lecz ChRL.

31 Oczywiście trudno jest mówić o otwartym zbliżeniu tych państw, jednak ich polityka strategicznie się zbliża, co przy formalnym zaangażowaniu Saudów w Lidze Państw Arabskich może korzystnie wpływać na chęć normalizacji relacji z Izraelem. 
Sytuacja w Syrii jest niepokojąca, ponieważ dotychczasowy reżim był dla Izraela przewidywalnym, łatwym w ocenie zagrożeń potencjalnym przeciwnikiem. Perspektywa ,irakizacji” tego państwa, pogrążenie go w chaosie, bądź uzależnienie od nieprzyjaźnie nastawionej w chwili obecnej w stosunku do Izraela Turcji, czy wzrost wpływów Iranu, wzmacnia zagrożenie płynące z tamtego kierunku. Trzeba postrzegać tę sytuację z perspektywy historycznej rywalizacji otomańsko-perskiej, nabierającej praktycznego wymiaru na początku XXI wieku. Rywalizacja Turcji z Iranem zawsze była obecna na obszarze Azji Środkowej, Iraku oraz Syrii. Alawickie rządy w Syrii obawiają się zbliżenia z sunnicką Turcją (otomańska Turcja w przeszłości rządziła Syrią przy pomocy arabskich - sunnickich elit). Wewnętrzna rywalizacja w Syrii, związana z wydarzeniami arabskiej wiosny, może mieć wymiar sojuszu alawicko-irańskiego, przeciwko sojuszowi sunnito-tureckiemu ${ }^{32}$. Na taką sytuację nie mogą być obojętne władze Arabii Saudyjskiej, gdyż po upadku H. Mubaraka wzrasta jej rola, jako lokalnego lidera. Osłabienie pro-irańskiego reżimu Alawitów w Syrii leży w jej interesie.

Wydarzenia „Arabskiej wiosny” wywarły także wpływ na dialog ${ }^{33}$ izraelsko-palestyński. Porozumienie jest utrudnione w związku z faktyczną dwuwładzą po stronie palestyńskiej, z jednej strony rządzący w Gazie, zdecydowanie antyizraelski Hamas, z drugiej - władze Autonomii Palestyńskiej, kontrolujące Zachodni Brzeg. Do czasu upadku rządów H. Mubaraka, Egipt dążył do osłabienia Hamasu (związanego z Bractwem Muzułmańskim), wspierał dialog i był rzecznikiem porozumienia. Teraz sytuacja diametralnie się zmieniła. Sztandarowe przedsięwzięcie na drodze normalizacji tzw. mapa drogowa, popierana przez Egipt, Arabię Saudyjską, Jordanię, Bahrajn, traci swoje fundamenty, nie sprzyja mu utrata wiarygodności USA w regionie. Izrael w tym kontekście może postrzegać zachowanie Stanów Zjednoczonych, jako wyraz osłabienia międzynarodowych gwarancji, dotyczących procesu pokojowego z Palestyńczykami. $\mathrm{W}$ tę lukę mogą wejść regionalni gracze i ich interesy, związane z rywalizacją wewnętrzną, co niekoniecznie musi sprzyjać dialogowi, pokojowi i normalizacji izraelsko-palestyńskiej. To zaś dla Izraela może oznaczać przeniesienie sytuacji ciagłego konfliktu i wzmożonego alertu militarnego, tak, jak to ma miejsce w przypadku kontrolowanej przez Hamas Strefy Gazy. „Arabska wiosna” stworzyła sytuację braku kontroli Półwyspu Synajskiego i zwiększone możliwości uzupełnienia arsenałów Hamasu, co zwiększa zagrożenie terytoriów Izraela. Sytuacja ta sprzyja również większej infiltracji Gazy przez wspierający Hamas, wrogi Izraelowi Iran. Całkowite, ostateczne zdobycie władzy przez islamistów w Egipcie może zdecydowanie zmienić możliwości oddziaływania Izraela w Strefie Gazy i kontrolę Hamasu. Dlatego ze strategicznego punktu widzenia, nie jest wykluczone przeprowadzenie przez Izrael, zdecydowanej operacji militarnej przeciwko Hamasowi jeszcze na początku 2012 r., co niewątpliwie wpłynie na wzrost nastrojów antyizraelskich wśród społeczeństw regionu.

32 Konflikt w Syrii nabiera rozmachu, walki sił rządowych i opozycji trwają od kilku miesięcy, dopływ informacji jest utrudniony, w styczniu 2012 r. doszło do spektakularnych zamachów samobójczych w Damaszku. Może to wskazywać na powtórkę „,scenariusza” z Iraku.

33 Świadomie używam określenia „,dialog”, a nie „konflikt”, gdyż od lat osiemdziesiątych $\mathrm{XX}$ wieku toczy się proces określany mianem negocjacji pokojowych, mają miejsce kolejne próby ostatecznego uregulowania sytuacji. 
Końcowym wątkiem dotyczącym wniosków płynących z „Arabskiej wiosny” mogą być kwestie związane z Al Kaidą oraz jej ewentualnym wzmocnieniem, bądź osłabieniem, co nie jest bez znaczenia dla Izraela oraz całego regionu. Wielu komentatorów uważa, iż wydarzenia w państwach arabskich to faktyczny powiew wiatru dla tej organizacji, trudno żeby nie wzbudzało to zaniepokojenia w Izraelu ${ }^{34}$. Izrael nie może sobie pozwolić na idealistyczne postrzeganie „Arabskiej wiosny” i traktować demokracji, jej zwiastunów jako leku na całe zło w regionie, w tym porażkę i kres Al Kaidy, o czym niejednokrotnie spekulują analitycy z Zachodu. Faktyczny upadek tej organizacji, spadek jej wpływów i popularności w muzułmańskich społeczeństwach, będzie można obwieścić dopiero, gdy dojdzie do faktycznego sukcesu obecnych rewolucji. Dopiero postęp społeczno-ekonomiczny oraz odczuwalne, trwałe zmiany w tym względzie po upadku autorytarnych reżimów, mogą być przeciwwagą dla islamskiego radykalizmu głoszonego przez Al Kaidę. Zbyt wcześnie na optymistyczne wnioski zwiastujące jej kres.

Mając na uwadze przedstawione powyżej fakty, należy uznać, że pełne uzasadnienie ma użycie stwierdzenia, iż arabska wiosna jest początkiem ,ery niepewności”. Czas pokaże jakie będa jej długofalowe konsekwencje. Izrael nie może sobie pozwolić na nieuzasadniony optymizm i błędne oceny, dlatego musi być przygotowanym na negatywne scenariusze, ponieważ zarówno elity tego państwa, jak i społeczeństwo maja świadomość, iż w razie porażki tzw. drugiej szansy nie będzie.

Analiza powyżej przedstawionych faktów, a także spekulacje dotyczące potencjalnego rozwoju sytuacji w regionie oraz bezpośrednim otoczeniu Izraela, wskazują, iż powinien on przyspieszać rozwój swojego potencjału militarnego, rozwijać dziedziny odpowiednie dla istniejących oraz powstałych zagrożeń. Musi on jednak zachowywać powściągliwość w użyciu instrumentów militarnych, gdyż „era niepewności”, która nastała po arabskiej wiośnie sprzyja powstawaniu antyizraelskich sojuszy w regionie. Przez ostatnie dekady Armia Izraela (IDF) była nastawiona na stabilną sytuacją związaną z wschodnim frontem, dzisiaj ta sytuacja musi się zmienić. Użycie siły przeciwko Hamasowi, będzie bez wątpienia przez nowy rząd Egiptu, inaczej odbierane i mniej tolerowane, niż operacje z 2006 czy 2008 r. w epoce H. Mubaraka. Przyszłe operacje militarne, jeśli do takich dojdzie, będą musiały być błyskawiczne, najwyżej kilkudniowe, po to by Egipt nie musiał zbyt długo tłumaczyć swojej powściagliwości. Może to oznaczać w przypadku narastania konfliktu z Hamasem, tendencje do jego dozbrajania, penetracji przez wrogie Izraelowi ugrupowania, konieczność częstszych interwencji, niż dotychczas.

Najbardziej problematyczna, z punktu widzenia obserwatorów zewnętrznych, wydaje się być kwestia militarnego powstrzymania przez Izrael nuklearnych planów Iranu. Tutaj również wydarzenia arabskiej wiosny wprowadzają istotną jakość, powściagliwość USA, jej postawa wobec zagrożeń związanych z upadkiem dotychczasowych reżimów, może wzmocnić zwolenników koniecznego ataku prewencyjnego, ponieważ ewentualne spekulacje na temat intencji USA, mogą wzbudzać wątpliwości. Takie rozwiązanie bę-

34 Argumenty dla tych komentarzy, wiążą się z ocenami, iż protestujący wcale nie dążą do demokracji w zachodnim rozumieniu, nie są jej rzecznikami. Zob.: Y. Schweitzer, G. Stern, A Golden Opportunity? Al-Qaeda and the Uprisings in the Middle East, „Strategic ASSESSMENT” 2011, vol. 14, no 2, s. 29. 
dzie wzmacniało antyizraelskie nastawienie wśród Arabów, z czego Izrael zdaje sobie sprawę i musi wkalkulować to w ewentualne swoje działania oraz ich konsekwencje.

Izrael w swojej ocenie sytuacji strategicznej musi brać pod uwagę zarówno czynniki zewnętrzne, jak i wewnętrzne. Fakty o charakterze strategicznym, to twarde realia, z którymi to państwo musi się oswajać od dziesiątków lat, dzisiaj sytuacja jeszcze bardziej się zaostrzyła, co niekoniecznie musi być zrozumiałe dla opinii międzynarodowej, z którą Izrael pośrednio musi się liczyć w realiach medialnych współczesnego świata $^{35}$. Z drugiej strony presja wewnętrzna jest nie mniejsza. Dlatego w strategicznym interesie Izraela jest trzymanie, na tyle, na ile jest to możliwe, nici współpracy z Egiptem, Jordanią oraz Turcją, a także podjęcie prób rozwoju form kooperacji z Arabią Saudyjską. Generalizując, bardzo ważne z punktu widzenia interesów tego państwa jest i będzie łagodzenie napięć i konfliktów w regionie.

$$
* * *
$$

Odpowiedzi na pytania postawione na wstępie, w kontekście strategicznego bezpieczeństwa Izraela, z punktu widzenia świata zewnętrznego, mogą wydawać się dziwne. Jednakże Izrael musi być silnie osadzony w realiach, nie może sobie pozwolić na błędy, ponieważ te moga oznaczać kres jego egzystencji.

„Arabska wiosna” wpłynęła i w dalszym ciągu wpływa na pogorszenie sytuacji strategicznej Izraela. Musi to pociagać za sobą konsekwencje związane ze zwiększeniem nakładów na infrastrukturę militarną, konieczność szukania nowych rozwiązań, wzmożone operacje wywiadowcze i kontrwywiadowcze. Reakcja USA, stopień zaangażowania się państw UE wskazuje, iż w obecnych realiach interesy sojuszników, sposób postrzegania regionu, niekoniecznie muszą być zbieżne z interesami i bezpieczeństwem strategicznym Izraela.

Zmiany zachodzące w regionie mogą mieć bardzo istotne znaczenie dla konfliktu arabsko-izraelskiego i to w wymiarze negatywnym. Wskazuje na to możliwość przejęcia całkowitej władzy przez islamistów w Egipcie, a także perspektywa podobnych zmian w Syrii i dojścia do władzy islamistów i powstania państwa islamskiego. Rywalizacja o wpływy w regionie oraz całym świecie arabskim, może nasilić się przez chęć większego wpływania na kwestie konfliktu izraelsko-palestyńskiego przez różnych graczy. Taka sytuacja może skłonić Izrael do nasilenia operacji militarnych w Gazie oraz konieczności podobnych działań na Zachodnim Brzegu. Rządy państw arabskich znajdą się wtedy po raz kolejny pod presją antyizraelskich nastrojów, fali protestów, zamachów i chęci zemsty, co zaostrzy konflikt arabsko-izraelski. Po osłabieniu, a być może całkowitej utracie dotychczasowych sojuszników w Egipcie oraz Turcji, a także osłabieniu zaangażowania USA w regionie, Izrael może postrzegać jako potencjalnych sojuszników zagrożone rewolucją państwa Zatoki Perskiej. Przewodzi im Arabia Saudyjska, dla której zmiany kojarzą się z rosnącym zagrożeniem ze strony Iranu oraz rodzimych ekstremistów islamskich. Arabia Saudyjska nie może sobie pozwolić na

35 Medialny charakter przedsięwzięć wojennych i ich antyizraelski charakter uzmysłowiła mu dobitnie wojna libańska z 2006 r. 
oficjalny sojusz z Izraelem, jednak interesy strategiczne obu państw są w wielu przypadkach tożsame. Nie tylko Izrael pilnie obserwuje poczynania wrogo nastawionego, próbującego zrealizować swój militarny program atomowy Iranu. Fakt bycia przez Iran mecenasem szyickiej opozycji w monarchiach Zatoki, czyni go wspólnym wrogiem, nie tylko Izraela. Ewentualny upadek Bashara al-Assada w Syrii osłabi irańską strefę wpływów w Azji Południowo-Zachodniej. Może natomiast nasilić chęć jego ideologicznego oddziaływania na arabskie społeczeństwa przez nasilenie działań przeciwko Izraelowi.

Stąd wnioski dotyczące wpływu burzliwych zmian roku 2011 na sytuację strategiczną Izraela mają zdaniem autora, charakter pesymistyczny. Sytuacja jest nadal dynamiczna, wiele teoretycznie może się zmienić, myślenie w kategoriach strategicznych, zwłaszcza związanych z zagrożeniami militarnymi, musi zakładać scenariusze negatywne, gdyż błędy w ocenie mogą być niezwykle kosztowne.

\title{
STRESZCZENIE
}

Celem niniejszego artykułu jest dokonanie oceny wydarzeń w Afryce Północnej, określanych mianem „Arabskiej wiosny ludów”, z perspektywy strategicznych interesów Izraela. Trudno rozpatrywać jakiekolwiek zmiany na Bliskim Wschodzie bez uwzględnienia specyficznego miejsca i roli tego państwa. To, co ważne dla regionu i całego świata, dla Izraela oznacza konieczność oceny z perspektywy jego bezpieczeństwa, dotychczasowego układu sił, korzyści i strat związanych ze zmianami, prognoz dotyczących procesów politycznych i społecznych w kontekście zagrożeń, prognoz długoterminowych bez charakterystycznego entuzjazmu dla zmian samych w sobie. Euforia medialna czy entuzjazm polityczny, charakterystyczny dla ocen przemian demokratycznych w państwach północnej Afryki przez państwa spoza regionu (również USA i państw UE), dla Izraela oznacza alert, konieczność przewartościowania dotychczasowych ustaleń. Istnienie dotychczasowych reżimów, które nie dopuszczały do ekspansji radykalnego islamu, było korzystne dla izraelskich władz. „Arabska wiosna” jest odbierana w Izraelu, a także przez analityków z nim związanych, jako początek „ery niepewności”. Zwycięstwo islamistów we wszystkich niedawnych wyborach - w Egipcie, Tunezji, Maroku, zarysowuje tendencję odchodzenia od świeckich autokratycznych reżimów na Bliskim Wschodzie na rzecz reżimów islamskich o różnym stopniu radykalizacji. Sytuację może jeszcze bardziej zaostrzyć podobny proces w Libii oraz Syrii. To wszystko zwiększa stan napięcia i prawdopodobieństwo radykalizacji nastawienia wobec Izraela, jej narzędziem może być Hamas w Autonomii czy Hezbollah w Libanie. Z punktu widzenia Izraela, istnieją poważne obawy, iż ostateczne wyniki wyborów w Egipcie otworzą drogę do rychłej wojny egipsko-izraelskiej. Egipscy islamiści mogą chcieć zniszczyć swojego głównego politycznego konkurenta - armię, poprzez wojnę z jakimkolwiek silnym przeciwnikiem, a tym jest jedynie Izrael.

\section{POLITICAL CHANGES IN THE ARAB WORLD IN 2011 FROM THE PERSPECTIVE OF ISRAEL'S STRATEGIC SECURITY INTERESTS}

\begin{abstract}
The end of 2010 and the beginning of 2011 in Arab countries marked its place in history as the Arab Spring or the Arab Awakening, since during this period mass social, political and eco-
\end{abstract}


nomic protests could be observed in almost all the countries in the region. Due to the nature, dynamics and the issues underlying the Arab-Israeli conflict, each and every material change in Arab countries is and has to be important for Israel and the whole Middle East. Considering the phenomenon being analyzed from the perspective of the Arab-Israeli conflict and Israel's external and internal situation, in my opinion it is particularly important to attempt to answer the following question: Has the Arab Spring changed Israel's strategic situation, and if so, to what extent? Looking at the ensuing situation from the perspective of Israel and also the Arab-Israeli conflict, at the very beginning we can have doubts or an opinion even less optimistic than in Europe about the nature of these changes. The Arab Spring may be regarded by Israel and also by the analysts related with the country as the beginning of the „era of uncertainty”. This is mainly connected with the changes regarding political regimes and the possibility of coming to or sharing power with Islamic movements and parties hostile towards Israel. The collapse of political regimes was accompanied by failures of the ruling political parties connected with these regimes. The gap was filled by dozens of new parties, with religious and Islamic parties being particularly strong. Time will show its long-term consequences. Israel cannot afford unjustified optimism and false opinions, and that is why it has to be prepared for negative scenarios since both the country's elites and society are aware of that there may be no second chances in event of failure. 
